\title{
EFFECT OF VIRGIN COCONUT OIL ON SKIN INTEGRITY IN THE ELDERLY WITH INCONTINENCE
}

\author{
Sukhri Herianto Ritonga ${ }^{*}$, Nanda Masraini Daulay ${ }^{2}$ \\ 1,2 Universitas Aufa Royhan \\ Padangsidimpuan- Sumatera Utara \\ Email*: nerssukhri88@gmail.com
}

\begin{abstract}
Intorduction:Incontinence was a problem that often occurs in the elderly and this condition can worsen the elderly situation with the appearance of severe damage to the integrity of the skin,Virgin Coconut Oil (VCO) contains medium chain saturated fat that easily enters deep skin layers and maintains skin elasticity and suppleness. The aim of this study was to determine the effect of virgin coconut oil on skin integrity in the elderly with incontinence.Methods: The design of research was a quasi-experimental with non equivalent control group design. The population in this study were all elderly who experience incontinence. The sampling technique used was consecutive sampling with a total of 10 people in the experimental group and 10 people in the control group. To assess skin integrity before and after treatment is used was The Ghent Global IAD (GLOBIAD) tool. The using of virgin coconut oil is done every time after the stool incontinence episode and after bathing. Virgin coconut oil has been applied to the damaged skin and also to other vulnerable skin. Results: Based on the Wilcoxon test results obtained p value smaller than 0.05 which is 0.010 so that there was a significant difference in the value of skin integrity before and after the treatment. Conclusions:There was a significant effect on the use of virgin coconut oil on skin integrity in the elderly with incontinence.
\end{abstract}

Keywords: elderly; incontinence; virgin coconut oil; skin integrity

\section{INTRODUCTION}

Increasing the number of elderly continues to occur along with the increasing life expectancy of global life, including in Indonesia. After nearly five decades the number of elderly people has doubled to $8.97 \%$ or 23.4 million people. This number will continue to grow, where by 2021 the number of elderly will reach $10 \%$ of the entire population of Indonesia (BPS, 2018). This situation will certainly cause new problems for the elderly along with the functional decline of the elderly body. The decline in bodily functions will occur as a whole and will result in a decrease in the quality of life of the elderly and increasingly dependence on others as we age.

Health problems that arise with increasing age are incontinence problems. Incontinence occurs in more than one fifth of the elderly who are more than $85 \%$. This incontinence is a result of decreased nerve and muscle function, so sufferers will find it difficult to control elimination normally. Incontinence is a health problem in the form of the patient's inability to control urine or feces.
These incontinence can occur either or both (Simpson, 2016)(Woodward, 2016)(Wilson, 2015). This situation can worsen the quality of life of the elderly if not handled properly, especially on the integrity of the skin that is directly in contact with urine or feces.

According to (Beeckman D et al., 2015) the skin through its outermost layer maintains skin moisture under ideal conditions. The stratum corneum regulates incoming or outgoing fluid, preventing overhydration or dehydration so that the skin remains in proper hydration and can function properly. However, the condition of incontinence causes the skin to be continuously exposed to fluids, causing the skin to be unable to maintain its moisture so that there is damage to the skin.

Handling the integrity of the skin so that it remains in optimal condition is very important to note. There were 2 interventions that could be done for the treatment of skin structure, namely by cleanse and protect. (Voegeli \& Health, 2017) (Beeckman D et al., 2015). Cleanse is performed to remove urine or feces from the surface of the skin and must be done before the protective action. Protect itself 
is placing a barrier or protector on the skin to prevent direct contact with urine and feces. Various types of products can be used to treat the structure of the skin. The product characteristics that could be given are clinically able to prevent or be able to overcome damage to the integrity of the skin, match the ph of the skin, the potential for low irritation, transparent, comfortable to use, accepted by clients and other health professionals, cost effective.

Virgin Coconut Oil (VCO) is oil made from fresh coconut meat, processed with controlled heating or without heating at all. VCO contains medium chain saturated fat that easily enters deep skin layers and maintains skin elasticity and suppleness. Lauric acid and capric acid contained in virgin coconut oil (VCO) can kill viruses, these compounds include monoglyceride compounds that are as antiviral, antibacterial, antibiotic, and antiprotozoal (Nurah, WMADB, Ranil, Isona, $\&$ Vijay, 2017). According to the research of (Cahyati, Idriansari, \& Kusumaningrum, 2015) one of the natural ingredients that can be considered as an alternative topical therapy that can be used for skin care in infants with diaper rash and as a prevention of diaper rash is virgin coconut oil (VCO). Based on this research, VCO affects diaper rash in infants and can be recommended for treatment and prevention of diaper rash in infants. The aim of this study was to determine the effect of virgin coconut oil on skin integrity in the elderly with incontinence.

\section{METHODS}

The design of this study was a quasiexperiment in which the research subjects will be given treatment and will be assessed before and after the treatment. The approach used is a non equivalent control group design where there will be two groups, namely the control group and the experimental group.

The population in this study were all elderly who experience incontinence while the sample will be taken using consecutive sampling techniques. The specified inclusion criteria are elderly with incontinence, suffering from grade 1 incontinence associated dermatitis and not using skin care products on vulnerable skin areas.

The number of samples to be taken in this study were 10 people in the experimental group and 10 people in the control group.The measuring instrument used to assess the integrity of the skin is The Ghent Global IAD (GLOBIAD) categorization tool. The Ghent Global IAD (GLOBIAD) categorization tool has been agreed internationally to describe the appearance of the IAD clinic (Young, 2017).

Research Procedure start with:

1. Making VCO:

a. Old coconut fruit with fresh grated flesh of 1000 grams and then added $1500 \mathrm{~mL}$ of water and squeezed to produce coconut milk. Coconut milk is allowed to stand for \pm 2 hours to be taken part of the cream. 50 grams of a mixture of young papaya fruit skin and leaves containing papain added $500 \mathrm{~mL}$ of water and then blended until smooth.

b. The juice from the blender after that was filtered then the remaining pulp is removed to obtain papain juice extract which is then added slowly to the coconut milk cream and stirred for 20 minutes.

c. Incubation for 24 hours produced 3 layers, namely the top layer was the VCO followed by the blondo, and water (Suaniti, Manurung, \& Hartasiwi, 2014).

2. Implementation

a. This action will be assisted by research assistants who will previously be explained in full research procedures. This action is carried out so that researchers and research assistants have the same understanding of research procedures.

b. After the informed consent process has been completed as described above, the research team will then review the condition of the respondent's skin and fill it into the research instrument sheet. Furthermore, after each fecal incontinence episode and / or after each bath was done 
in the morning, an even VCO application will be applied to all damaged skin and other vulnerable skin. Then the respondent was positioned again as it should be.

c. Each will apply a VCO, then the skin condition will be assessed. This action will continue until the respondent has recovered or until the time limit specified was 7 days for each respondent . VCO is given after every bowel movement and after every shower in the morning.

d. During the course of the study, researchers empowered family members to provide VCO to respondents. Researchers have prepared $\mathrm{VCO}$ on the bottle packaging, so that the family members simply spray the VCO evenly on the blushed body parts.
The research team will evaluate the implementation of research every day to the respondent's home.

This study was approved by the ethical committee of the Faculty of Nursing, University of North Sumatra Number:1953/III/SP/2019

Univariate analysis is used to provide an overview of each variable using the frequency distribution and percentage of each variable. The bivariate analysis used was the chi square test to see differences in skin integrity after the action between the experimental group and the control group. Next, the smear test was performed to see differences in skin integrity in the experimental group before and after the action is given.

\section{RESULTS}

Table 1. Frequency distribution of respondent characteristics

\begin{tabular}{llll}
\hline No & Charateristics & N & $\%$ \\
\hline 1 & Age & & \\
& Elderly & 9 & 45,0 \\
& Old & 9 & 45,0 \\
& Very old & 2 & 10,0 \\
\hline & Total & 20 & 100,0 \\
\hline 2 & Sex & & \\
\hline \multirow{4}{*}{ Male } & 2 & 10,0 \\
& Female & 13 & 90,0 \\
\hline Total & Duration of IAD & 20 & 100,0 \\
\hline 3 & < 1 month & & \\
& 1-3 month & 19 & 95,0 \\
& $>3$ month & 1 & 5,0 \\
\hline & Total & 0 & 0,0 \\
\hline 4 & Upper Arm Circumference & 20 & 100,0 \\
\hline & Obesity & & 0,0 \\
& Overweight & 0 & 0,0 \\
& Normal & 0 & 0,0 \\
& Underweight & 0 & 100,0 \\
\hline & Total & 20 & 100,0
\end{tabular}

Based on the table above (table 1), that all patients were elderly and most were in the elderly category, namely age 60-65 years and the old category, age 66-80 years. Based on gender, the majority of respondents were female at $90 \%$. Based on the duration of IAD, 
the majority of respondents who suffered from incontinence associated dermatitis were less than one month or $95 \%$ and based on upper arm circumference (upper arm circumference) all respondents had underweight category.

Table 2. The frequency distribution of respondents' skin integrity disorders before and after the treatment in the experimental group

\begin{tabular}{llccccc}
\hline No & Skin Integrity & \multicolumn{2}{l}{ Pre } & \multicolumn{3}{c}{ Post } \\
\cline { 3 - 7 } & & $\mathrm{n}$ & $\%$ & $\mathrm{n}$ & $\%$ \\
\hline 1 & Normal & 0 & 0,0 & 5 & 50,0 \\
2 & Redness without infection & 1 & 10,0 & 3 & 30,0 \\
3 & Redness with infection & 8 & 80,0 & 1 & 10,0 \\
4 & Skin loss without infection & 1 & 10,0 & 1 & 10,0 \\
5 & Skin loss with infection & 0 & 0,0 & 0 & 0,0 \\
\hline & Total & 10 & 100,0 & 10 & 100,0 \\
\hline
\end{tabular}

Based on the table above (table 2), the condition of the integrity of the skin of the experimental group respondents prior to the action of the majority of redness with infection
(80\%) and after the action was carried out the condition of the integrity of the respondent's skin was better that was in good condition $(50 \%)$.

Table 3. Frequency distribution of skin continuity of respondents before and after the treatment in the control group

\begin{tabular}{llrrccc}
\hline No & Skin Integrity & \multicolumn{2}{c}{ Pre } & \multicolumn{3}{c}{ Post } \\
\cline { 3 - 7 } & & $\mathrm{n}$ & $\%$ & $\mathrm{n}$ & $\%$ & \\
\hline 1 & Normal & 0 & 0,0 & 0 & 0,0 \\
2 & Redness without infection & 2 & 20,0 & 5 & 50,0 \\
3 & Redness with infection & 8 & 80,0 & 5 & 50,0 \\
4 & Skin loss without infection & 0 & 20,0 & 0 & 0,0 \\
5 & Skin loss with infection & 0 & 0,0 & 0 & 0,0 \\
\hline & Jumlah & 10 & 100,0 & 10 & 100,0 \\
\hline
\end{tabular}

Based on the table above (table 3), the condition of the integrity of the skin of the control group respondents before the action of the majority was reddish with infection and after the action there was a change but remained in the reddish condition either with infection or without in.

Table 4. Differences in skin integrity before treatment in the experimental and control groups.

\begin{tabular}{|c|c|c|c|c|c|c|c|c|c|}
\hline \multirow{3}{*}{ Type of group } & \multicolumn{6}{|c|}{ Skin Integrity } & \multirow{2}{*}{\multicolumn{2}{|c|}{ Total }} & \multirow{3}{*}{$p$ value } \\
\hline & \multicolumn{2}{|c|}{$\begin{array}{l}\text { Redness } \\
\text { without } \\
\text { infection }\end{array}$} & \multicolumn{2}{|c|}{$\begin{array}{l}\text { Redness } \\
\text { with } \\
\text { infection }\end{array}$} & \multicolumn{2}{|c|}{ Skin loss } & & & \\
\hline & $\mathrm{n}$ & $\%$ & $\mathrm{n}$ & $\%$ & $\mathrm{~N}$ & $\%$ & $\mathrm{~N}$ & $\%$ & \\
\hline Experiment & 1 & 5,0 & 8 & 40,0 & 1 & 5,0 & 10 & 50 & \\
\hline Control & 2 & 10,0 & 8 & 40,0 & 0 & 0,0 & 10 & 50 & 1,000 \\
\hline Total & 3 & 15,0 & 16 & 80,00 & 1 & 5,0 & 20 & 100 & \\
\hline
\end{tabular}


Based on the table above (table 4), a p value of 1,000 was obtained which means it was greater than 0.05 . Then it could be concluded that there was no significant difference in the integrity of the skin before the action either in the experimental group or the control group.

Table 5. Differences in skin integrity after treatment in the experimental and control groups

\begin{tabular}{|c|c|c|c|c|c|c|c|c|c|}
\hline \multirow{3}{*}{ Type of group } & \multicolumn{6}{|c|}{ Skin Integrity } & & & \multirow{3}{*}{$p$ value } \\
\hline & \multicolumn{2}{|c|}{ Normal } & \multicolumn{2}{|c|}{$\begin{array}{l}\text { Redness } \\
\text { with and } \\
\text { without } \\
\text { infection }\end{array}$} & & & \multicolumn{2}{|l|}{ Total } & \\
\hline & $\mathrm{n}$ & $\%$ & $\mathrm{n}$ & $\%$ & $\mathrm{n}$ & $\%$ & $\mathrm{~N}$ & $\%$ & \\
\hline Experiment & 5 & 25,0 & 4 & 20,0 & 1 & 5,0 & 10 & 50 & \\
\hline Control & 0 & 0,0 & 10 & 50,0 & 0 & 0,0 & 10 & 50 & 0,164 \\
\hline Total & 5 & 25,0 & 14 & 70,00 & 1 & 5,0 & 20 & 100 & \\
\hline
\end{tabular}

Based on the table above, a $\mathrm{p}$ value of 0.164 was obtained which means it was greater than 0.05 . Then it could be concluded that there was no significant difference in the integrity of the skin after the action in the experimental group and the control group. However, based on the frequency distribution it was appeard that in the experimental group there were more conditions of good skin integrity compared to the control group.

Table 6. Differences in skin integrity before and after the control group

\begin{tabular}{|c|c|c|c|c|c|c|}
\hline \multirow[t]{2}{*}{ No } & \multirow[t]{2}{*}{ Skin Integrity } & \multicolumn{2}{|c|}{ Pre } & \multicolumn{2}{|c|}{ Post } & \multirow[t]{2}{*}{$p$ value } \\
\hline & & $\mathrm{n}$ & $\%$ & $\mathrm{n}$ & $\%$ & \\
\hline 1 & Normal & 0 & 0,0 & 0 & 0,0 & \\
\hline 2 & $\begin{array}{l}\text { Redness } \\
\text { infection }\end{array}$ & 2 & 20,0 & 5 & 50,0 & \\
\hline 3 & Redness with infection & 8 & 80,0 & 5 & 50,0 & 0,083 \\
\hline 4 & $\begin{array}{l}\text { Skin loss without } \\
\text { infection }\end{array}$ & 0 & 20,0 & 0 & 0,0 & \\
\hline 5 & Skin loss with infection & 0 & 0,0 & 0 & 0,0 & \\
\hline & Total & 10 & 100,0 & 10 & 100,0 & \\
\hline
\end{tabular}

Based on the table above (table 6), a p value of 0.083 was obtained which means it was greater than 0.05 . Then it could be concluded that there was no significant difference in the integrity of the skin before and after the control group.

Table 7. Differences in skin integrity before and after the experimental group

\begin{tabular}{|c|c|c|c|c|c|c|}
\hline \multirow[t]{2}{*}{ No } & \multirow[t]{2}{*}{ Skin Integrity } & \multicolumn{2}{|c|}{ Pre } & \multicolumn{2}{|c|}{ Post } & \multirow[t]{2}{*}{$p$ Value } \\
\hline & & $\mathrm{n}$ & $\%$ & $\mathrm{n}$ & $\%$ & \\
\hline 1 & Normal & 0 & 0,0 & 5 & 50,0 & \\
\hline 2 & $\begin{array}{l}\text { Redness } \\
\text { infection }\end{array}$ & 1 & 10,0 & 3 & 30,0 & \\
\hline 3 & Redness with infection & 8 & 80,0 & 1 & 10,0 & 0,010 \\
\hline
\end{tabular}


Jurnal INJEC Vol. 4 No. 2 December 2019: 105-112

\begin{tabular}{llrrrr}
4 & $\begin{array}{l}\text { Skin loss without } \\
\text { infection } \\
5\end{array}$ & 1 & 10,0 & 1 & 10,0 \\
$\begin{array}{l}\text { Skin loss with } \\
\text { infection }\end{array}$ & & 0,0 & 0 & 0,0 \\
\hline Total & 10 & 100,0 & 10 & 100,0 \\
\hline
\end{tabular}

Based on the table above (table 7), a $\mathrm{p}$ value of 0.01 is obtained which means it was smaller than 0.05 . Then it could be concluded that there were significant differences in the condition of skin integrity before and after treatment in the experimental group.

\section{DISSCUSSIONS}

Based on the results of the study, it was generally obtained that there is an influence of the use of VCO on skin integrity in patients with IAD. This result could be seen both statistically univariate and bivariate tests, as well as through observations where IAD which contained 5 respondents $(50 \%)$ in the experimental group with good skin integrity after giving this VCO.

The results of this study were in line with various previous studies such as research conducted by (Cahyati et al., 2015). The results of his study showed that VCO was effective in treating diaper rash, based on statistical tests it showed a significant difference in the degree of diaper rash before and after VCO administration. However, according to research conducted by (Setyawati, Suyanto, \& Noor, 2015), VCO has not been proven effective when applied to pressure sores. Where the pressure sores have special treatment that is by wound care.

Decubitus sores are injuries caused by excessive pressure on certain sides of the body. (Bhattacharya \& Mishra, 2015) So giving interventions to reduce pressure on the affected skin becomes a top priority. Furthermore, wound care must be done with the concept of moisture balance to accelerate the growth of new tissue in the wound. While the use of VCO itself is more appropriate for skin that occurs redness (dermatitis) not the skin that has been injured. According to (Beeckman D et al., 2015; Voegeli \& Health, 2017) management of skin integrity due to incontinence consists of 2 interventions namely washing and protecting.

Washing is an action to remove urine and feces or other substances from the surface of the skin that was susceptible. Usually, this washing was done using soap, water and a washing cloth that we use every time the client finishes defecating and urinating to remove urine, feces and other liquids. However, the soap that we usually used was alkaline soap in which the soap will interfere with acid levels in the skin in order that, it would be ultimately damage the structure of the skin.(Beeckman D et al., 2015) (D., S., T., K., \& L., 2011; Stephen-Haynes, 2017)

After washing, the skin must be protected immediately to prevent skin damage. Skin protection is used when preventing or overcoming the problem of skin damage. This skin protector will create a barrier between the stratum corneum and any irritants including urine or feces (Beeckman D et al., 2015). Through the results of this study, the use of VCO can be one of the products that could be used as a protector on the skin due to this incontinence. This can be done because VCO has medium saturated fat content that can maintain skin moisture from excess fluid from urine or feces. In addition, VCO will also protect the skin from the invasion of various microbes. Lauric acid and capric acid contained in virgin coconut oil (VCO) can kill viruses, these compounds include monoglyceride compounds that are as antiviral, antibacterial, antibiotic, and antiprotozoa (Nurah et al., 2017)

\section{Limitation of this study}


This research is a basic type of research in revealing the effectiveness of VCO to overcome the occurrence of dermatitis due to incontinence. In general, the VCO content is very safe to use for the skin, however, the VCO content is certainly very diverse from one another. In this study, exploration of the VCO content has not been carried out maximally, so to conclude which VCO content has the most role has not been revealed. So for further research is needed to determine the content. So that in the future it can be modified the content and efficacy of VCO is more effective.

\section{CONCLUSIONS}

After conducting research it could be concluded that the majority of respondents were in the age range of 60 to 80 years with the majority being female. Then the majority of respondents suffer from incontinence associated dermatitis for less than 1 month and all have LILA measures in the underweight category.

According to the wilcoxon statistical test, there was a significant difference in the integrity of the skin before and after the action in the experimental group while in the control group there was no significant difference

Based on the results of the study several things are suggested,

This study has explored the use of VCO on skin integrity in the elderly with incontinence. In order that, policy makers in the health service need to take policies that can accommodate the used of VCO in incontinence care.

Nursing managers are expected to develop Operational Procedure Standards for the use of VCO in incontinence care, so that the use of VCO can be implemented at the level of nursing practice.

Acknowledgments were conveyed by researchers to the DPRM, Minitstry of Research, Technology and Higher Education for budding lecturer research grants so that the results of this study could be published right at international seminars.

Likewise, a thank you to the University of AufaRoyhanPadangsidimpuan as a place for researchers to pursue careers and strive to present the best work for progress and mutual prosperity, especially in the fields of health and nursing.

\section{REFERENCES}

Beeckman D et al. (2015). Proceeedings of the global IAD Expert Panel. IncontinenceAssociated dermatitis: moving prevention forward. Wound Internacional.

Bhattacharya, S., \& Mishra, R. (2015). Pressure ulcers: Current understanding and newer modalities of treatment. Indian Journal of Plastic https://doi.org/10.4103/09700358.155260

BPS. (2018). 2018 , Jumlah Penduduk Indonesia Mencapai 265 Juta Jiwa. 2018. https://doi.org/10.1016/j.ecolind.2011.11. 011

Cahyati, D., Idriansari, A., \& Kusumaningrum, A. (2015). Pengaruh Virgin Coconut Oil Terhadap Ruam Popok Pada Bayi. Jurnal Keperawatan Sriwijaya.

D., B., S., V., T., D., K., V., \& L., S. (2011). A 3-in-1 perineal care washcloth impregnated with dimethicone $3 \%$ versus water and $\mathrm{pH}$ neutral soap to prevent and treat incontinence-associated dermatitis: A randomized, controlled clinical trial. Journal of Wound, Ostomy and Continence Nursing.

Nurah, T. O., WMADB, F., Ranil, C., Isona, G., \& Vijay, J. (2017). Effect of extraction techniques on the quality of coconut oil. African Journal of Food Science. https://doi.org/10.5897/ajfs2016.1493

Setyawati, R., Suyanto, S., \& Noor, M. A. (2015). PENGARUH MOBILISASI DAN PENGGUNAAN VCO (VIRGIN COCONUT OIL) TERHADAP ULKUS DEKUBITUS PADA GANGGUAN FUNGSI MOTORIK PASCA STROKE. Nurscope: Jurnal Penelitian Dan Pemikiran Ilmiah Keperawatan. https://doi.org/10.30659/nurscope.1.2.1-6 Simpson, P. (2016). Excellence in continence care: An overview. British Journal of 
Nursing.

https://doi.org/10.12968/bjon.2016.25.2.9 2

Stephen-Haynes, J. (2017). Skin care and barrier protection. Wound Essentials.

Suaniti, N., Manurung, M., \& Hartasiwi, N. (2014). UJI SIFAT VIRGIN COCONUT OIL (VCO) HASIL EKSTRAKSI ENZIMATIS TERHADAP BERBAGAI PRODUK MINYAK KELAPA HASIL PUBLIKASI. Jurnal Kimia.

Voegeli, D., \& Health, S. (2017). Prevention and management of incontinenceassociated dermatitis. 26(20).
Wilson, M. (2015). Living with faecal incontinence: A 10-year follow-up study. British Journal of Nursing. https://doi.org/10.12968/bjon.2015.24.5.2 68

Woodward, S. (2016). Supporting patients to manage faecal incontinence. British Journal of Nursing. https://doi.org/10.12968/bjon.2016.25.7.3 70

Young, T. (2017). Back to basics: Understanding moisture-associated skin damage. Wounds UK. 